\title{
Formal Bibliography in the Upper Division
}

Miss Diehl, formerly librarian, Texas Lutheran College, was associate professor, Louisiana State University Library School, summer, 1955 .

$\mathrm{C}$ OLLEGE AND UNIVERSITY JUNIORS are at the peak of their need for the tools of study. Lower division courses are filled with textual data which form the basic material for advanced college and graduate study. The upper division courses revolve about bits of individual study-usually reported in the term paper, and sometimes in several such papers. These reports are not simply exercises in English composition. They circle some phase of the subject matter under consideration.

Institutions offering the four-year college curricula have the basic bibliographic tools. They are used in the operation of the institutional library-actually used by the teaching and the library staffs in book selection. These same books and catalogs are useful to the students in the school as they prepare studies in a subject of individual choice. Authors, author's ideas, book titles which are perennially popular or evanescent, subjects of immediate interest-all these come to the attention of the thoughtful student of bibliographies.

The bulk of readings actually necessary for a course usually will be found within the immediate college library. Frequently neighboring libraries can enrich the readings for students. Knowledge of the holdings within a community is usually not certain until the various libraries are visited, but the use of printed bibliographies can expedite the selection of reading matter in the other collections because the choices have been made prior to the actual visit. A student reader who knows what he wants is usually a very welcome guest. Such a visitor should not expect to borrow books for home use -but mutual benefit is gained when privileges for building use extend to other campuses after the resources at home have been exhausted. Unless the student can be certain that his home facilities have been exhausted, he will gain little by going abroad for help. Reference room staffs have little time to devote to visitors, nor have visitors any right to expect it. Books are the goal, not guidance. The guidance must be provided in the student's own school. Alert librarians will welcome both the opportunity to provide the bibliography course work for their own students and the sharing of materials with visiting readers.

Some faculty members will consider it a great waste of student time to insist on a two-hour requirement in advanced bibliography. Those instructors probably will be the older ones who went to college and university some forty years ago-before so many bibliographies were compiled and written. But it is this same generation of faculty who has professed faith in the phrase, "The library is the heart of the institution." The heart, represented by staff and books, is there, ready and eager to function. Now and then a bit of artificial respiration is necessary. The books are dead unless they flow. Hence all the paraphernalia of bibliography is necessary before the books come alive in the college. 
Once the basic bibliographic tools are understood by the college junior, the assignments coming from the various courses will indicate the value of practices already learned and the need for more specific source books. By the time the junior has become a senior he will be sad to think of the freshmen and their simple encyclopedias! $\mathrm{Nu}$ merous graduating seniors continue working in vocations requiring library usage. $\mathrm{Li}$ brary staffs vary in size, and book collections vary greatly in content. It is academic courtesy to teach the many ways to find information. Teachers in small communities have limited facilities at hand, yet there are inexpensive journals to help in public school curriculum and administration. Research assistants in industrial laboratories will have vast resources of a technical nature at their command, but only the simple matter of how knowledge is organized can locate answers.

Some few college students will continue study in graduate schools. Fortunate are those whose ability is beyond that of the reserve book library, or the small departmental collection. Occasional college curricula are so fringed by reserves that young graduates have no notion of the resources actually available. It is too late when they learn some of the tricks of study and individual research. Sometimes it is so much too late that an extra semester is necessary to complete a thesis, or that bibliographic detail is entirely inadequate in dissertation footnotes. This cannot be blamed entirely on the student. Until quite recently there was little realization of the need for $a d$ vanced freshman library orientation. Suddenly the need arose in humanities and civilization courses, with their numerous and varied readings and materials, for some students to reach beyond their capacity. Those who had the techniques of good library use passed. The others failed. Librarians saw the problem, and its solution.
Numerous institutions are insisting on formal study of bibliographic materials as part of the graduate school program of studies. If it be necessary at the stage of advanced study, it was needed at the undergraduate level where facilities for course work were certainly less ample, and where numerous libraries in the community were serving the interested young reader. Strangely-but not so strange, really - those colleges with strong individual instructional programs have high academic standards all the time. The small college that tries to skip the essentials of good study habits, good library habits, thorough classroom preparation by both students and faculty, is the school that believes a few books will satisfy to teach and/or pass a course.

The cost in student load or staff time for the two-hour bibliography is negligible. The facilities of the immediate book collection will become useful. New titles are perennially available. Actually, except in pure and applied science and in creative art and literature, there is little really new. Versions, transcriptions, and editorialized copies come fresh every day. But the really new ideas come, as mentioned, in the pure or applied science and the creative art and literature. All physical volumes wear thin from use-and storage. Replacements, new editions, and variant readings are necessary. No library needs all of these variants to meet student requirements. Students who are trained in the use of materials actually on the shelves-and $99 \%$ of the time that which is on order can be disregarded until next semester!-will find double or triple the detail which untrained readers will locate. Those who are adept in bibliography can be easily trusted in the stacks. They understand the reasons and need for library routines, for good library manners. They gladly "Do not shelve books" and "Tip books, please." They even "Do not sit in the aisles" and are happy! Furthermore, 
their ability to sift details, to find the way to original authorship, to trace ideas to their source, is so superior to the ability of the untrained reader that there is no comparison. The student produces completed problems. The person without bibliographic techniques is lost.

Why some schools have been hesitant to offer students full use of library facilities is somewhat difficult to understand. The course work required need involve no more staff, though it will involve an academic and instructional alert. Teaching loads are usually measured at fifteen or sixteen classroom hours per week. That would indicate one teaching staff member could handle seven or eight sections of junior students. That is a lot of juniors! Further loadspread can be secured by dividing the course responsibility between the library and the departmental personnel - the librarians carrying the teaching load to the point of specialized bibliographies, and the departmental teaching staffs taking responsibility for those special materials. By this method a really fine interplay of teaching and resources is indicated to every young person of junior standing on the campus. Mutual respect of the instructional and library staff will be at high level. And, because department heads tend to be among the older members of the faculty in point of service, they will be forced to do such serious digging as some have not done since their Ph.D. days thirty years ago. Bibliography beware: you who are on the library staff are in for a merry chase too!

After all of the program is in action, will a heavier load fall on the library reference room? No. That load will be carried by the entire faculty and by all of the trained upper division students. The unusual questions will reach the reference desk, but the head reference librarian will be the logical candidate for the title, professor of bibliography. His influence will be exerted by means of mass communication, rather than by individualized instruction. The "little learning" can become maturing wisdom. The "making of books" will continue, and libraries will purchase the best of them. Wise instruction in their use is practical and inexpensive. It is certainly one of the requisites of scholarship.

Outline of a Program:

\section{Objectives}

I. Understanding the ways in which knowledge is organized; and appreciation of the privilege and responsibility of an education.

II. Facility in the use of print, near-print, and photographic editions.

III. Understanding the basic theories of library organization so that (a) Use of community libraries will be natural and easy for the college graduates; (b) Children of these future parents and teachers will be encouraged to read for both pleasure and profit; and (c) Communities into which these graduates move will be encouraged to provide basic libraries and collections of the writings of the present day.

\section{Procedure}

I. Brief, perhaps two-hour, study of the history of the book.

II. The various kinds of materials available today, thus studying the standards modern books meet.

III. Basic books vs. ephemera.

IV. Books of reference as important tools to the use of the entire collection.

$V$. The details of a few very specific titles in each category; with problems involving their use.

VI. The need for standardization of methods for recording things read, books mentioned, and segments of larger works; i.e., the relative ease of using a bibliography which is consistent in form, and the parallel ease of making such a bibliography.

VII. The study of bibliography coordinated with the actual reading-writing-study problems of the students in the class.

VIII. At least one-fourth of the course pre- 
sentation to be made by members of the various departmental teaching faculties, with careful coordinate preparation by the bibliographer and faculty member.

IX. Presentation by each student of a paper to give evidence of a specific problem understood, and partially solved. The paper may be evaluated by both instructors, so that the subject matter is criticized from the viewpoint of the subject specialist, and the bibliographic detail by the librarian or bibliographer.

\section{The Core for Bibliography in the Upper Division}

I. Bibliographic style.

A. Style manual for campus. If none is already accepted, try Turabian, Manual for Writers of Dissertations, University of Chicago Press. It is inexpensive, practical, and quite generally acceptable.

B. Comparison of accepted manual with variants; and/or comparison of the various acceptable forms in use on the local campus. If this condition exists, attempt to reconcile the proponents of the various styles, and to devise a campus-wide form which will not require deviation for graduate work.

II. Books.

A. Formal details required for book identification; the parts of a book.

B. Essential bibliographies:

I. Public card catalog

a. Catalog card and its variant data.

b. Filing system in actual campus use.

c. Subject heading list in actual campus use-a copy of this list to be easily available at all times at the desk nearest the catalog.

2. Shelf list:

a. Catalog card and its data.

b. Filing system in actual use.

c. Classification schedule followed. A copy of this schedule to be easily available at all times at the desk nearest the shelf list catalog; and another copy of the schedule at the circulation desk if the stacks are open to the students.

3. Local union catalogs of community resources.

4. The CBI and U.S. Catalog.

5. LC depository catalog and its descendants.

6. PTLA and Books in Print.

7. Public documents:
a. Monthly Catalog and its 1941-50 Index.
b. Document Catalog.
c. Monthly Checklist of State Publications.

8. Comparable works, I-7 above, issued in other countries and other languages than English.

III. Periodicals.

A. Formal details required for periodical reference identification; the gathering of issues to make volumes, etc.

B. Essential bibliographies:

I. Public card catalog, if local indexing is included.

2. Readers' Guide studied as a type index, using How to Use the

Readers' Guide (N. Y.: Wilson, latest ed.) as a brief text.

3. Comparison of entry for periodicals in the acceptable style manual with the norm accepted by the Wilson Co.

4. Examine and contrast other periodical indexes; the N.Y. Times Index, Facts on File, etc., as available.

5. Comparable indexes issued by other countries and in other languages than English.

IV. General reference.

A. Encyclopedias:

I. Formal organization: indexes; authorship; revisions and reprints; recency ; coverage of subject matter; etc.

2. Foreign works locally available.

B. Dictionaries :

I. Vocabulary, i.e., one-language dictionaries.

2. Bilingual, classical and modern languages.

3. Subject, i.e., small-scale encyclopedias. 
V. Subject reference.

A. Encyclopedias, as above.

B. Dictionaries, as above.

C. Bibliographies, as in Encyclopedias (IV, A, above). (At this point emphasize the overlapping of subjects, and the consequent seeming discrepancy in book classification; i.e., not all the books on Chaucer will be in the 80o's, nor all those on Peace in the I7o's).

VI. Bibliographies of general reference.

(This is the place in the course to emphasize the ease of access to subject matter via the bibliography, as opposed to the awkward method of simply going to the stacks to find a book. Stress the practice followed by librarians who know their book collection almost perfectly, of using some bibliographic tool before going to the shelf. If printed and card bibliographies be wasted effort, then many libraries are filled with books that should be discarded, and the scholar who has let the compilation of the "monster" overpower him is the only person who will profit. But common practice has proved the usefulness of bibliographies. Become acquainted with them; learn those which are especially useful in general matters, and those which have a specialty.)

A. Useful books:

I. ALA Catalog Series. Chicago, ALA.

2. Collison, R. L. Bibliographies, Subject and National (N. Y.: Hafner, I95I).

3. Guide to Reference Books, ed. by Mudge and Winchell. (Chicago: ALA) (6th ed. by Mudge is not superseded by the 7 th ed. by Winchell. Notice suppl. to 7 th ed., 1954).

4. Malclès, L.-N. Les sources $d u$ travail bibliographique. (Geneva, Droz: Lille, Giard, I950- ) ( $2 \mathrm{v}$. in 3 are available; v. 3 , not yet issued).

5. Shores, L. Basic Reference Sources. (Chicago: ALA, 1954).

6. Standard Catalog Series. (N.Y.: Wilson).
B. Ephemera:

I. Vertical File Service Catalog, 1932- . (N. Y.: Wilson).

2. Current periodicals listing free and inexpensive materials.

VII. Bibliographies of specific reference.

(This is to be directed to particular student interest, in major and minor subject fields. Work may proceed by committees or groups if the one instructor must be concerned with the entire responsibility for the course. Where it is coordinated, members of the subject teaching faculty taking the instruction in their major fields, the instruction will be more formal. The size of the classes, the number of the instructional staff, and the number of class sections will determine the procedure during this unit).

Problem: Choose a very definite subject, with the approval of the instructor. Gather references from sources available on the campus (or within a specific library area, or using particular libraries within the city-at the specific option of the instructor). Present (a) a formal bibliography, which follows the accepted style manual exactly, and (b) a preface or introduction which indicates command of the bibliographic tools and complete use of the necessary subject matter.

Note: Problems involving the use of the various tools would have been assigned periodically as studied. The larger problem, just above, would be evaluated at $\frac{1}{4}$ to $\frac{1}{3}$ of the entire course credit. If the faculties coordinate with the presentation of this course, the problem may be closely tied with a departmental assignment. But only when the exact details are determined by the bibliographer and the teaching faculty, before the assignment of the problem, may dual credit be earned. 